E3S Web of Conferences 1, 20005 (2013)

DOI: $10.1051 / \mathrm{e} 3$ sconf/20130120005

(c) Owned by the authors, published by EDP Sciences, 2013

\title{
Tracer Elements analysis of Aerosols in the Atmosphere of Lahore using Radio analytical techniques
}

\author{
S. Ata ${ }^{1}$, M. A. Qadir ${ }^{1}$ and A. Rasool ${ }^{1}$ \\ ${ }^{1}$ Institute of Chemistry, University of the Punjab, Lahore-54590, Pakistan
}

\begin{abstract}
The perturbations of atmospheric processes by anthropogenic activities of man have been of great concern these days. The deposition of trace and major elements from the atmosphere to the ground is an important factor for animal and plant health, and it is of major consideration in studies on the cycling of elements that may function in the atmosphere as nutrients or potentially toxic pollutants. When assessing the input of materials in natural waters and land, the sources and composition of atmosphere need to be determined. Geological and anthropogenic contributions to air pollution were monitored by analyzing aerosol particulates present in the atmosphere of Lahore. Various sorts of experiments were performed for studying total suspended particulate matter (TSPs) using gravimetric techniques. The average value of TSPs was found $450 \mathrm{ug} / \mathrm{m}^{2}$ in working days and $240 \mathrm{ug} / \mathrm{m}^{2}$ in holidays. Their size distribution and trace elemental composition and their wet removal through precipitation in the atmosphere of Lahore was studied by using scanning electron microscopy (SEM) and instrumental neutron activation analysis (INAA) respectively. Eighteen elements were analyzed. Geological nature of the land was attributed the presence of $\mathrm{Yb}, \mathrm{Cs}, \mathrm{Sc}, \mathrm{Rb}, \mathrm{Co}, \mathrm{Eu}$, $\mathrm{La}, \mathrm{Ba}, \mathrm{Zn}$ and $\mathrm{Hf} \mathrm{s}$ in the aerosol particulates. The presence of $\mathrm{Cr}, \mathrm{Fe}, \mathrm{Ce}, \mathrm{Pb}$ and $\mathrm{Cd}$ could be linked to anthropogenic activities. Their amount was two times higher than the limits reccomended by the U.S. Environmental Protection Agency for the urban environment, mostly during working days and at various day and night time.
\end{abstract}

Key Words: Aerosols, Air pollution, Trace elements, INAA, Precipitation and Urban Environment.

\section{Introduction}

Aerosol particulates in the atmosphere signify geological, environmental and anthropogenic activities. Thus, it is important to have a complete considerate of these three aspects pertaining to the sites under mega city (Lahore) in Pakistan. (Colbeck. I et al, 2010) Lahore is the second largest city of Pakistan. It is $1305 \mathrm{~km}$ to the North-East of Karachi at $74.3^{\circ} \mathrm{E}$ and $31.5^{\circ} \mathrm{N}$ on global scale, at a height of 213 meter from sea level. Its 2251 square kilometer metropolitan area has near about 10 million populations with 2000 persons per square mile population density and $4.5 \%$ per annum expanding rate. The effect of atmospheric aerosols on human health strongly depends on their capability to penetrate the respiratory tract. Generally, the smaller particles penetrate into the respiratory system more profoundly. Coarse particles may deposit in the pharynx and larynx, causing dryness of the nose and throat but have no effect on the mucociliary clearance. Environmental protection agency emphasis is aimed at developing air quality standards based on the specific size fraction of particles, which can reach the trachea (J. J. Chow et al 1973, M. Kanakidou. et al 200). The upper cut-off limit has been proposed for inhalable particles having size of $10-15 \mu \mathrm{m}$ diameter. The choice of the $15 \mu \mathrm{m}$ cut off point is based on the worst case situation of mouth breathers, because in nose breathers particles larger than $10 \mu \mathrm{m}$ are either rejected by the nose or restricted to the nasopharyngeal region.

\section{Materials and Methods}

\section{Sampling Parameters and its strategy}

Sampling was carried out in sunny days and the sampling interval was kept for at least $24 \mathrm{~h}$. The days were randomly chosen for the sampling of the aerosol particulates. High volume portable dust sampler Model L30 MK III of Rotheroe and Mitchell Company (U.K) having sampling capacity of $40 \mathrm{~L} / \mathrm{min}$ were used throughout the work. For the determination of wind velocity and directions, three cup anemometer type DEM 6 made of Tientsin Meteorological and Marine Instrument of China were used. Before sampling 
Whatman-41 filter papers were washed in de-ionized water, while Whatman microfiber glass filter paper were soaked in dilute $\mathrm{HCl}$ for half an hour, washed with excess of de-ionized water and fired at $500{ }^{\circ} \mathrm{C}$. Prior to their loading into the sampler, they were equilibrated to their weight at $55 \%$ relative humidity and $25{ }^{\circ} \mathrm{C}$ to eliminate the effect due to the hygroscopic nature of the filter papers. The filters having $6 \mathrm{Cm}$ diameter $(28 \mathrm{Cm}$ exposed area) were loaded in the sampler equipped with mass flow indicator and sampling time counter. Duplicate and some time triplicate sampling were carried out. Five sampling stations were installed at the Institute of Chemistry University of the Punjab old and new campus, Ichra, Gulberg and Shahdara under the sampling conditions as described above. Sampling was also carried out during working days, holidays, and rainy days, after rain fall and at various day and night hours. Each Sampling was carried out for 24- $144 \mathrm{~h}$ duration, during which 50-350 $\mathrm{m}^{3}$ air was sampled. Sampling parameters e.g. weight of blank filter paper, sampling rate, climate, temperature, humidity, total sampling hours and total volume of air sampled were also recorded during sampling. During scavenging process the sampler was put in a position that it was safe from the direct exposure to rain, but wind freely force the sampler from all directions for sampling.

Determination of the TSPS, size distribution and morphological structure of the aerosol particulates

Total suspended particulate matter was measured by using standard gravimetric technique. Scanning electron microscope model JSM-35F was used for the evaluation of the size distribution and morphological structures of the aerosol particulates trapped on the surface of the filter paper media. The amount of TSPs and size distribution pattern of the aerosols in the atmosphere of Lahore may be seen in Table-1 and 2. The SEM of aerosol is shown in fig. 1 .

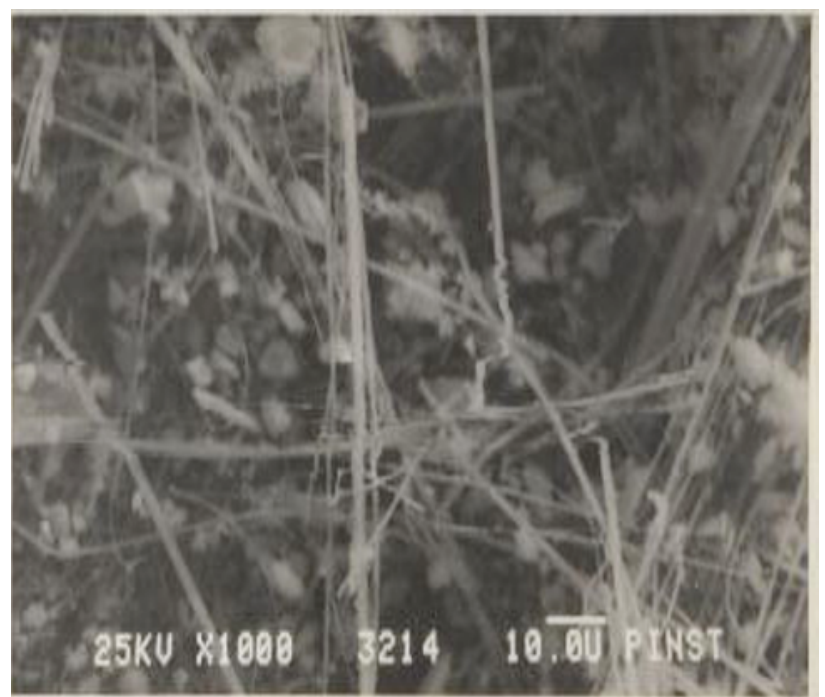

Fig.1. Morphological structures of the aerosol particulates in the atmosphere of Pakistan

\section{Activation and Analysis}

In order to carry out neutron activation analysis, quartz ampoules of the air filtered sampled and blank filters along with the ampoules of the appropriate amounts of IAEA and NBS standard reference materials e.g. Marine sediments MS (IAEA/SD-D-1/2), Pond Sediment (PS) and Lake Sediment (SL-1 \& SL-3) were cold welded in aluminum capsules, and were irradiated for different durations in the periphery of reactor core of the Pakistani Research Reactor (PARR-1) at thermal neutron flux of 3$7 \times 10^{13} \mathrm{n} \mathrm{Cm}^{-2} \mathrm{~S}^{-1}$. Thermal neutron monitors (Au and Co foils) were inserted between the samples and reference materials to monitor the fluctuations in the thermal neutron flux gradient and these were found to be insignificant. The irradiated samples and standards after cooling for 1-14 days were transferred to pre-weighed polyethylene capsules. The gamma ray spectra were measured for varying time ranging from $1 \mathrm{~h}$ to $16 \mathrm{~h}$ with a coaxial $30 \mathrm{Cm}^{3} \mathrm{Ge}(\mathrm{Li})$ detector, with a FWHM of 2.0 $\mathrm{keV}$ for the $1332.5 \mathrm{keV}$ peak of ${ }^{60} \mathrm{Co}$ and a peak to Compton ratio of $40: 1$, coupled to a $4 \mathrm{~K}$ Series 85 Canberra multichannel analyzer. The multichannel analyzer (MCA) was calibrated with standard point sources of ${ }^{60} \mathrm{Co}$ and ${ }^{137} \mathrm{Cs}$ (from M/S Ammersham) prior to sample and standard analysis. The amount of the elements was calculated by making the use of relative method. The precision, reproducibility and accuracy of this method were checked by analyzing MS and SL-1 IAEA reference materials and may be seen in somewhere else (M. Z. Iqbal et al 1992). About 11 trace elements were analyzed by NAA technique; However $\mathrm{Pb}$ and $\mathrm{Cd}$ were measured by standard AAS techniques. The details of AAS techniques for the determination of $\mathrm{Pb}$ and $\mathrm{Cd}$ may be seen some where (M. Z. Iqbal et al 1990). The results thus obtained are given in Table-III.

\section{Results and Discussion}

\section{Total suspended particulate matter and their size distribution}

The amount of the total suspended particulate matter (TSPs) on working days at Lahore was obtained in the range of $350-511 \mu \mathrm{g} / \mathrm{m}^{3}$ with an average of $450 \mu \mathrm{g} / \mathrm{m}^{3}$, its amount decreased to $160-300 \mu \mathrm{g} / \mathrm{m}^{3}$ with an average of $240 \mu \mathrm{g} / \mathrm{m}^{3}$ on non- working days. The amount of TSPs during 9.0 p.m. to 3.0 a.m. at Lahore was $215 \mu \mathrm{g} / \mathrm{m}^{3}$ which further decreased to $190 \mu \mathrm{g} / \mathrm{m}^{3}$ at 3.0 a.m. to 9.0 a.m. The amount of TSPs again increased from 10.0 to 4.0 p.m. at about $470 \mu \mathrm{g} / \mathrm{m}^{3}$, which indicated high anthropogenic activity in evening times. The amount of TSPs at Lahore decreased to $80 \mu \mathrm{g} / \mathrm{m}^{3}$ during precipitation and after 24 hours its amount approached to $140 \mu \mathrm{g} / \mathrm{m}^{3}$. It is interesting to know the differences of $24 \mathrm{~h}$ sampling and $12 \mathrm{~h}$ sampling system. Shorter sampling systems usually do not give accurate and reliable results as compared to long-term sampling systems (W. C. Achinger et al 1968). The TSPs at Lahore on working days were of the order of $450 \mu \mathrm{g} / \mathrm{m}^{3}$ on $24 \mathrm{~h}$ sampling basis, where as at day or night hours (12h sampling) the 
amount of the TSPs was 590 and $550 \mu \mathrm{g} / \mathrm{m}^{3}$ respectively. The higher amounts of the TSPs at night hours may be explained due to the peak traffic density i.e. 5.0 p.m. to 10.0 p.m. The traffic density decreases tremendously after midnight as shown by the data given in Table-1.The size distribution of the aerosol particulates in the atmosphere of Lahore is given in Table-2.

\section{Trace elemental composition of the aerosol particulates}

The major source of $\mathrm{Yb}, \mathrm{Cs}, \mathrm{Sc}, \mathrm{Rb}, \mathrm{Co}, \mathrm{Eu}, \mathrm{La}, \mathrm{Ba}$ and Hf in the atmosphere has been reported to soil derived aerosols (P P. Parekh et al 1987, P. P. Parekh 1989). The amount of $\mathrm{Yb}, \mathrm{Cs}$ and $\mathrm{Sc}$ in the atmosphere of Lahore was in the order of $0.92 \pm 0.2,32.7 \pm 5.7$ and $2.75 \pm 0.71$ $\eta \mathrm{g} / \mathrm{m}^{3}$ respectively. Although the main source of $\mathrm{Sc}$ is soil-derived aerosols, but some workers have also linked its presence to un-refined fuel as well (Y. Hashimoto et al 1970). The amount of $\mathrm{Rb}, \mathrm{Co}$ and $\mathrm{Eu}$ in the atmosphere of Lahore was $24.8 \pm 5.1,4.1 \pm 0.3$ and $2.5 \pm 0.27 \eta \mathrm{g} / \mathrm{m}^{3}$, while $\mathrm{La}$ and $\mathrm{Ba}$ was $10.3 \pm 1.15,11.1 \pm 2.3 \eta \mathrm{g} / \mathrm{m}^{3}$. Like other Chalcophillic elements ( $\mathrm{Sc}, \mathrm{S}, \mathrm{Cu}, \mathrm{Pb}$ and $\mathrm{Cd}$ ), $\mathrm{Zn}$ is also recognized as chalcophillic elements. The sources of $\mathrm{Zn}$ into the atmosphere are coal-burning plants, sulphide ore smelters, and refuse incinerations ( $\mathrm{P}$ P. Parekh et al 1987, P. P. Parekh 1989). The amount of $\mathrm{Zn}$ in the atmosphere of Lahore was $16.1 \pm 1.36 \mathrm{\eta g} / \mathrm{m}^{3}$. The sources of Se in the environment have been reported from coal rather than oil (Y. Hashimoto et al 1970, S. J. Tuncel et al 1985, S. J. Tuncel 1986). The amount of Se in the atmosphere of Lahore was found $11.5 \pm 3.21 \eta \mathrm{g} / \mathrm{m}^{3}$. Trace Elemental Composition of the Aerosol Particulates in the Atmosphere of Lahore in Table 3.

Many researchers (P. L. Kalhomaki et al 1984, P. G. J. Renzel et al 1984, H. J. Raithel et al 1988, Hansen at al 1985, A. Zober at al 1987, P.L. Kalliomaki at al 1987, Fujiware at all) have studied the effects of fumes having $\mathrm{Cr}$ on the lungs of human beings and on cells and pointed out that $\mathrm{Cr}$ may cause various sorts of diseases including cancer. Potassium dichromate is used in airconditioning and cooling towers and has been assigned as the source of $\mathrm{Cr}$ in Washington aerosols (U.S. Dept. of Health Education and Welfare 1966), but some workers have described that steel mills are the main source of $\mathrm{Cr}$ because $\mathrm{V}, \mathrm{Ni}, \mathrm{Fe}$ and $\mathrm{Cr}$ alloys are used for the manufacturing of various sorts of steel. The amount of $\mathrm{Cr}$ in the atmosphere of Karachi and Nilore (P P. Parekh et al 1987, P. P. Parekh 1989, A. Rasheed et al 1987) have been reported to be $24-26$ and $7.5 \mathrm{\eta g} / \mathrm{m}^{3}$ respectively, while in U.S.A. its amount was found ${ }^{21}$ to be in the range of $15.33 \eta \mathrm{g} / \mathrm{m}^{3}$. The amount of $\mathrm{Cr}$ in the atmosphere of Lahore was noted as $53 \pm 7.96 \eta \mathrm{g} / \mathrm{m}^{3}$. The amount of $\mathrm{Fe}$ in the atmosphere of Lahore was $14.3 \pm 2.3 \eta \mathrm{g} / \mathrm{m}^{3}$.

The sources of $\mathrm{Ce}$ in the atmosphere are expected to the almost entirely anthropogenic. Both $\mathrm{Ce}$ and $\mathrm{S}$ are mostly associated with fossil fuel combustion the amount of Ce in the atmosphere of Karachi ((P P. Parekh et al 1987) has been reported to be $6.5 \mathrm{\eta g} / \mathrm{m}^{3}$, while in the present work we have observed its amount in the range of $16.5 \pm 2.9 \eta \mathrm{g} / \mathrm{m}^{3}$ at Lahore. The amount of $\mathrm{Sb}$ in the atmosphere of Lahore was $2.57 \pm 0.1 \eta \mathrm{g} / \mathrm{m}^{3}$. (P P. Parekh et al 1987, P. P. Parekh 1989) found that the amount of $\mathrm{Pb}$ in the atmosphere of Karachi varied from $93 \pm 128$ to $274 \mathrm{\eta g} / \mathrm{m}^{3}$, and stated that automotive exhaust were the most important source of air-borne $\mathrm{Pb}$ in an urban atmosphere, especially that of Karach, where leaded gasoline is extensively used. Marshal (D. T. Marshall et al 1986) in 1985 found lead in aerosol particulates of Atlanta area in the range of $25.8 \pm 1090 \eta \mathrm{g} / \mathrm{m}^{3}$, with an average of $278 \mathrm{ng} / \mathrm{m}^{3}$ by using proton induced X-ray emission (PIXE) technique. (D. George Thurston et al 1985) reported mean $\mathrm{Pb}$ level as $326 \eta \mathrm{g} / \mathrm{m}^{3}$ mainly due to fine and coarse motor vehicle derived aerosols in metropolitan Boston. The amount of $\mathrm{Pb}$ in the atmosphere of Lahore was observed as $549 \pm 25 \eta \mathrm{g} / \mathrm{m}^{3}$. Cadmium comes into the atmosphere due to its presence in vehicle tire (M. Z. Iqbal et al, 1990). The amount of Cd in the atmosphere of Lahore was $20.5 \pm 5 \eta \mathrm{g} / \mathrm{m}^{3}$.

\section{References}

A. Rasheed, S. Ahmed, et al. A study of trace elements in the atmosphere of PINSTECH, NCD-109, 1987.

A. Zober, Weld. World 1987, 25(11-12), 246-247.

Colbeck I, Nasir ZA, Ali Z, The state of ambient air quality in Pakistan - a review, Environ Sci. Pollut Res Int. 2010; 17 (1):49-63

D. George Thurston and D. John Spengler, J. Atmos. Environ. 1985, 19(1), 9-29.

D. T. Marshall, E. M. Patterson. et al. J. Atmos. Environ., 1986, 20 (6), 1291-1300.

Fujiware and Kanta., Okayama Igakkai Zasshi, 101, 7/8, 733-42.

H. J. Raithel, K. H. Reith, Int. Arch. Occup. Environ. Health, 1988, 60(1), 55-66.

Hansen, Karen and Stern, TAT, j. Appl. Toxicol. 1985, 5(5), 306-14.

J. J. Chow, Chemistry in Britain, 1973, 9, 258.

M. Kanakidou. et al. J. Geophys. Res 2000; 105; 9243

M. Z. Iqbal, M. A. Qadir and J. H. Zaidi, Int. J. Environ. Anal. Chem., 1990, 39, 533-538.

M. Z. Iqbal, M. A. Qadir and J. H. Zaidi, J. Trace Elements and Electrolytes in Health and Disease, 1992, 6, 62-66.

P. G. J. Renzel, B. B. Beems, Rapp. TNO, Hoofolgrocp Voedings Middeless 1984, TNO, B85.522/000212, 43pp.

P. L. Kalhomaki, M. Olkinora, IARSC Sci. Pub. Nickel Hum. Environ. 1984, 53.

P. P. Parekh, Badar Ghauri and Liaquat Hussain. J. Atmos. Environ., 1987, 21 (6), 1267-74.

P. P. Parekh, Badar Ghauri and Liaquat Hussain. J. Atmos. Environ., 1989, 23 (7), 1435-1442.

P.L. Kalliomaki, A. Aitio, J. Aerosol. Sci., 1987, 18(6), 737-40.

S. J. Tuncel, I. Olmez, et al. J. Environ. Sci. Technol. $1985,19,529-537$.

S. J. Tuncel, Ph.D thesis, "Regional Scale Receptor Modeling in the North U.S.A., University of Maryland, 1986. 
U.S. Dept. of Health Education and Welfare, Air Quality Data from National Air Sampling Networks (196465), Public Health Division of Air Quality, Cincinnati Ohio, 1966.

W. C. Achinger and R. T. Shigehara, J. Air Pollut. Control Assoc., 1968, 18, 605.

Y. Hashimoto, J. Y. Hwang and S. Yanagisawa. J. Environ. Sci. Technol. 1970, 4, 157-158.

Table 1. Total Suspended Particulate Matter in the Atmosphere of Lahore

\begin{tabular}{|c|c|c|c|}
\hline S/No & $\begin{array}{l}\text { Sampling } \\
\text { Conditions }\end{array}$ & $\begin{array}{l}\text { Range of } \\
\text { TSPs }\end{array}$ & $\begin{array}{c}\text { Average } \\
\text { amount of } \\
\text { TSPs }\left(\mu \mathrm{g} / \mathbf{m}^{3}\right)\end{array}$ \\
\hline 1 & Working Days & $350-511$ & $450(24 h)$ \\
\hline 2 & Holidays & $160-300$ & $240(24 h)$ \\
\hline 3 & $\begin{array}{l}\text { At } 9.0 \text { a.m. to } 9.0 \\
\text { p.m }\end{array}$ & & $590(12 \mathrm{~h})$ \\
\hline 4 & $\begin{array}{l}\text { At } 9.0 \mathrm{p} / \mathrm{m} \text {. to } 9.0 \\
\text { a.m }\end{array}$ & & $550(12 \mathrm{~h})$ \\
\hline 5 & $\begin{array}{l}\text { At } 9.0 \text { a.m. to } 3.0 \\
\text { a.m }\end{array}$ & & $215(6 h)$ \\
\hline 6 & $\begin{array}{l}\text { At } 3.0 \text { a.m. to } 9.0 \\
\text { a.m }\end{array}$ & & $190(6 \mathrm{~h})$ \\
\hline 7 & $\begin{array}{l}\text { At } 10 \text { a.m. to } 4.0 \\
\text { p.m }\end{array}$ & & 360 (6h) \\
\hline 8 & $\begin{array}{l}\text { At } 4.0 \text { p.m. to } 10 \\
\text { p.m }\end{array}$ & & 470 (6h) \\
\hline 9 & During precipitation & & $80(24 h)$ \\
\hline 10 & After precipitation & & $140(24 \mathrm{~h})$ \\
\hline
\end{tabular}

Table 2. Size Distribution of the Aerosol Particulates in the Atmosphere of Lahore

\begin{tabular}{llc}
\hline S/No & Size $($ in $\boldsymbol{\mu} \mathbf{m})$ & Percentage (\%) \\
\hline 1 & $0.5-1$ & 27 \\
2 & $01-03$ & 30 \\
3 & $03-04$ & 19 \\
4 & $04-05$ & 07 \\
5 & $05-10$ & 15 \\
6 & $10-15$ & 03 \\
\hline
\end{tabular}

\begin{tabular}{|c|c|c|c|}
\hline \multicolumn{4}{|c|}{$\begin{array}{ll}7 & 15-20\end{array}$} \\
\hline \multicolumn{4}{|c|}{$\begin{array}{l}\text { Table 3. Trace Elemental Composition } \\
\text { Particulates in the Atmosphere of Lahore }\end{array}$} \\
\hline S/No & Element $\left(\eta g / \mathbf{m}^{3}\right)$ & $\gamma$-Ray (KeV) & Concentration \\
\hline 1 & ${ }^{141} \mathrm{Ce}$ & 145,239 & $16.5 \pm 2.9$ \\
\hline 2 & ${ }^{169} \mathrm{Yb}$ & 396,150 & $0.92 \pm 0.2$ \\
\hline 3 & ${ }^{75} \mathrm{Se}$ & 136 & $11.5 \pm 3.21$ \\
\hline 4 & ${ }^{51} \mathrm{Cr}$ & 320 & $53 \pm 7.96$ \\
\hline 5 & ${ }^{181} \mathrm{Hf}$ & 344 & --- \\
\hline 6 & ${ }^{134} \mathrm{Cs}$ & 605 & $32.7 \pm 5.7$ \\
\hline 7 & ${ }^{46} \mathrm{Sc}$ & 889 & $2.75 \pm 0.71$ \\
\hline 8 & ${ }^{86} \mathrm{Rb}$ & 1077 & $24.8 \pm 5.1$ \\
\hline 9 & ${ }^{59} \mathrm{Fe}$ & 1099 & $14.3 \pm 2.3$ \\
\hline 10 & ${ }^{60} \mathrm{Co}$ & 1173 & $4.1 \pm 0.3$ \\
\hline 11 & ${ }^{152} \mathrm{Eu}$ & 122 & $2.5 \pm 0.27$ \\
\hline 12 & ${ }^{140} \mathrm{La}$ & 487 & $10.3 \pm 1.15$ \\
\hline 13 & ${ }^{122} \mathrm{Sb}$ & 564.1 & $2.57 \pm 0.1$ \\
\hline 14 & ${ }^{99}$ Mo & 181,192 & ---- \\
\hline 15 & ${ }^{131} \mathrm{Ba}$ & 124 & $11.1 \pm 2.3$ \\
\hline 16 & ${ }^{65} \mathrm{Zn}$ & 1115 & $16.1 \pm 1.36$ \\
\hline 17 & $\mathrm{~Pb}^{*}$ & & $549 \pm 25$ \\
\hline 18 & $\mathrm{Cd}^{*}$ & & $20.5 \pm 5$ \\
\hline
\end{tabular}

(Average of 12 Samples)*By AAS. 